\title{
The Development of Biology Teaching Material Based on the Local Wisdom of Timorese to Improve Students Knowledge and Attitude of Environment In Caring the Persevation of Environment
}

\author{
Andam S. Ardan ${ }^{1}$ \\ ${ }^{1}$ Lecturer of University of Nusa Cendana, Indonesia \\ Correspondence: Andam S. Ardan, Lecturer of University of Nusa Cendana, Indonesia. E-mail: \\ andamsurianty@yahoo.com \\ Received: July 2, 2016 \\ doi:10.5430/ijhe.v5n3p190 \\ Accepted: July 20, 2016 \\ Online Published: August 11, 2016
}

\begin{abstract}
The purpose of this study were (1) to describe the biology learning such as lesson plans, teaching materials, media and worksheets for the tenth grade of High Schoolon the topic of Biodiversity and Basic Classification, Ecosystems and Environment Issues based on local wisdom of Timorese; (2) to analyze the improvement of the environmental knowledge of students after being given instructional materials, media and worksheets for the tenth grade of High Schoolon the topic of Biodiversity and Basic Classification, Ecosystems and Environmental Problems of East-based local knowledge; (3) to analyze the changes of students attitude after being given the biology learning material such as lesson plans, teaching materials, media and worksheets for the tenth grade of High Schoolon the topic of Biodiversity and Basic Classification, Ecosystems and Environment Issues based on local wisdom of Timorese.

This study use Research and Development ( $\&$ D) methods which consists of three phases of research. The first step is the analysis of necesity, the second step is designing and validating the learning product, the third step is the experiment to see the effectivness of the material in improving the environment knowledge and attitude of students in peservation the environment.

The result shows that the (1). The products such as Lesson Plan (RPP), grade tenth Biology textbook with Local Indigenous of Timorese for teachers and students, Student worksheet (LKS), learning media such as a micro director for Biodiversity materials, power point for each Biodiversity, Ecology and Environmental Science materials, Biodiversity map media and Puzzles ecosystem after being validated and tested-piloted turns valid and practical (2) The results of the experiment in tenth grade of Bio 2 SMAN 1 Kupang Barat shows that the which states that there is a difference in student achievement before and after the use of learning material are developed; (3) The experimental results for the attitude of the students in the tenth grade of SMAN 1 Kupang shows that the which states that there is a difference in students' attitudes before and after use learning developed material.
\end{abstract}

Keywords: Teaching material biology, Local wisdom of Timorese, Students knowledge, Environment caring

\section{Introduction}

One of the goals of national development as stated in the preamble of the Constitution of the Republic of Indonesia in 1945 is the intellectual life of the nation, and this could be interpreted literally by providing education that is specifically regulated in the legislation of the Republic of Indonesia No. 20 of 2003 on the national education system.

Factually learning can take place anywhere, anytime, and by anyone, and lasts long into the future. This fact makes the students at school actually doesn't come with an empty knowledge. They already have the initial knowledge gained from their environment whether families, housing, community, environment, or wherever they interact.

Then when their knowledge was added or enriched with material-material that is taught in school, then their initial knowledge is supposed to be reconstructed by means of providing new knowledge by not denyingtheir initial knowledge.

The subjects of biology as one of eyes learning at the secondary school level up (SMA) is the subjects included in the 12 (twelve) subjects with integrated environment according to the shared understanding between Depertemen of culture and education with the Ministry of the environment no. 0142/U/1996 with SK Minister of education and the Ministry of State for the environment no. 89/Download MOE/5/1996 about the construction and development of 
environmental education. Many topics on subjects of biology that can be developed to improve environmental knowledge and foster the attitude of maintaining the environment, because the basic science of biology is to learn about nature.

Biology becomes the means of insertion for students learning about environmental problems that could make the attitude of the students towards the environment for the better, because in biology students learn the needs of living things over his environment and the interaction of the two. Knowledge of biodiversity, ecosystems and the problemwill be the basis for environmental knowledge so that students are aware of the importance of the environment.

Through the contextual approach and salingtemas (environmental science technology and society) in the textbook Biology are expected to provide assistance to teachers in the associate between the material being taught with real world situations students and encourage students to make connections between knowledge assets with its application in everyday life as well as by looking at the potential of the local environment in particular local wisdom, which contains the traditional knowledge, natural resources and local culture, so that teachers can be utilized optimally in the learning process. This is one of the things that is recognized by curriculum 2013 i.e. recognition of individual differences and cultural background of the learners.

The potential of the local environment in particular traditional knowledge, local wisdom and local culture appears to have forgotten the lesson that teachers in. Teachers tend to be more wear materials so printed as Biology text books for sale. So the content of the material are not widespread, and national focus on local values that could be developed for teachers in classes related to the potential of the region. Based on observations and interviews and a biology teacher at the school in Kupang, dated May 13, 2013, then obtained the initial information that the teacher does not enter values of local or regional potential, tadisional, knowledge and local wisdom in some Biology learning topics such as biodiversity and basic classification, ecosystems and environmental issues.

Local wisdom that contains among other traditional knowledge as a Savior of the environment has been widely researched and examined experts. From their research can be views that there should be a bridge toconnect between the traditional knowledge with modern scientific and look for a way to integrate it within the system of formal learning at school so that students understand and will never forget the values of local culture of its own. To find out the benefits of traditional knowledge and local wisdom in improving environmental knowledge and attitude of students in safeguarding the environment, then a research development can be the first to explore a wide range of traditional knowledge and local wisdom that exist and thrive in the community, to later be integrated in learning devices in the form of RPP, learning materials, learning media and students worksheet.

Based on the above exposure, researchers want to uncover the role of learning Biology-based local wisdom of Timor in improving environmental knowledge and the formation of the attitude of maintaining environmental sustainability.

\section{Research Issues}

Some of the problems that will be revealed in this research are:

1. How does the description of the development of learning materials on Biological Biodiversity and the basic classification, ecosystems and environmental issues class X High School-based valid Timor local wisdom and practical?

2. Does the device learning material developed for Biological Biodiversity and the basic classification, ecosystems and the environment High Schoolclass X-based local wisdom Timor can effectively improve students environmental knowledge?

3. Does the device learning material developed for Biological material biological diversity and of the basic classification, ecosystems and the environment High Schoolclass X-based local wisdom Timor can effectively change the attitude of the students become better attitude in maintaining environmental sustainability?

\section{Research Objectives}

1. To develop and describe the biology of learning devices namely learning materials, media and students worksheet, $\mathrm{X}$-grade HIGH SCHOOLon the topic of biological diversity and of the basic classification, ecosystems and environmental issues-based local wisdom of Timor

2. To analyse the increasing environmental knowledge the students after learning of biology-based device given the local wisdom of Timor.

3. To analyze the changes in the attitude of the students in maintaining environmental sustainability after the given device learning Biology based local wisdom of Timor. 


\section{Research Methodology}

This research is a research and development with the assumption by application of learning with learning materials already developed expected increased environmental knowledge and attitude of students in maintaining environmental sustainability. Educational research and development (R D \&) is a process that can be used to develop and validate product education.

This research consists of three stages, namely the first stage is a form of survey research data search learning biology teacher in High Schoolthrough interviews with teachers and the principal, search local wisdom tribe Timor about the maintenance and care of the natural environment is relevant to Biological material grade $\mathrm{X}$ through interviews and observations with community leaders, teachers and people who expected to be able to provide information. Furthermore these values are integrated in the study of biology.

The second phase is the research development, which at this stage of local wisdom are found integrated in High School Biology class learning device X material for biological diversity and of the basic classification, ecosystems and environmental issues, in this RPP, learning materials, Media, students worksheet and THB. Furthermore the device that was made so it could be fixed and validated criteria learning materials that can be used as a handle for teachers and learning materials that already contains the local wisdom of Timor for material and basic classification of biodiversity, ecosystems and environmental issues, learning, media, Learning outcomes and tests (THB). Then the device that made the grade tested samples in the form of a small class of test and test large classes. The results of the test will produce a prototype device learning X-grade Biology.

The third phase is the research experiments to test whether the device learning developed can significantly improve environmental knowledge and attitude of students in maintaining environmental sustainability. Research phase 1 which is a research survey carried out in December 2013 to March 2014. School data retrieval as initial data development done in 4 schools namely SMA 1 West Kupang, Kupang Timur, SMA 1 SMA 1 middle and 1 High School Kupang Taebenu. Data for the development of the material taken with circulate kuisoner on teachers, community leaders and the general public who have the attention to the subject matter of the school. Data retrieval is done in Timor, local wisdom community tribe of East Timor in the village of Baumata sub-district of Taebenu Kupang.

Research phase 2 development was implemented in February to may 2014 in Kupang and Makassar because validation validation instruments and material involving 3 (three) expert: expert Materials in biology, and Environmental experts and expert education.

Further devices already validated called prototype 1 tested on test of small classes in August to September 2014. The results of the improvements will be put to the testa great class to get a prototype 2 in September and October 2014.

The third phase is the research experiments carried out on the Odd Semester T.A. 2014/2015 on a student's High SchoolNo. 1 County in West Kupang Kupang.

\section{a. Data analysis techniques}

One of the ultimate purpose of this development is the research to determine the effectiveness of the application of the device of traditional value-based Biology learning Timor in imparting knowledge about the environment, a positive change in attitude in taking part in preserving the environment. For the study of phase 1 data analyzed are descriptive.Research for phase 3, to test the validity of environmental knowledge test question researchers use qualitative validation that is by asking the teacher validates matter knowledge tests. From the results of a validation master, then it can be concluded that the products produced, namely a matter can already be tested cobakan at school. In addition, to strengthen, the author also did the validity of quantitatively, i.e., by testing the item reserved with mengeteskan on other classes. Validation of the grain problem is done by providing reserved to the students of Class XI. 2. SMAN 2 Central Kupang on 15 January 2014 the next student answer sheet in the validation.

From calculations using the Annates ver. 4 and manual, so it is known that from 30 items are tested to the students there is a valid question because $24 \mathrm{r}$ count $>\mathrm{r}$ table with $5 \%$ significance level and 6 problem that is not valid. Thus it can be used to question 24 for measuring students ability. While 6 other reserved discarded and replaced or altered composition editor question.

As for the effectiveness of data with experimental models of pre test post test of one group, the data value of the knowledge and attitude to be analyzed with statistical tests to test whether there are any changes before and after administering treatment with t-test correlated by using the following formula 


$$
t=\frac{\bar{D}}{\sqrt{\frac{\sum D^{2}-\frac{\left(\sum D\right)^{2}}{N}}{N(N-1)}}}
$$

Where:

$\mathrm{D}=$ difference between the average values of the test past knowledge and prior to using the device of learning developed

$\mathrm{N}=$ the number of students (Gay, 1981)

To test the validity of a test of attitudes is by finding and selecting the best statement of the validity of the test results was conducted. The validity of the tests carried out attitude at the same time with the test of knowledge, with the number of samplestudents alike. There are 30 items validated statement. The statement can best be seen from a statement item has different high power so that it can be separated between those who are included in the Group of respondents who have a positive attitude with which the respondents have a negative attitude.

When the entire correlation koeefisien statement has been found, then the smallestvalue that can be specified is considered high enough to be an indicator of the presence of consistency between statements and score score scale. The selected statement item is to take the item with a statement see coefficient of correlation with numbers high and get rid of any items that have a negative correlation statement or thatthe coefficient approaches zero $(0)$.

Thus all the data of the respondents about the attitude scale processed manually by mensubstitusikan all the results of the calculation to the formula that produces the product moment correlation validity of items and from the 30-question given to respondent/students there are 25 other 5 valid and invalid because thitung $<$ tminimal so 5 reserved will not be used/discarded.

\section{Results and Discussion}

\section{A. General overview Research Area}

Kupang regency is one of the 22 Counties that are located in the province of East Nusa Tenggara (NTT) province with three (3) large islands, namely East Timor, Sumbaand Flores and several small islands like Rote, Sabu, Pairs and others. Kabupen Gratin itself was on the island of Timor with the capital of the County is located in the Oelamasi began October 22, 2010, after the previous one is located in the city of Kupang since 1958. Kupang regency consists of 24 districts, 160 villages, and 17 village with an area of 5, 431, $23 \mathrm{~km}^{2}$ or Ha 543.123 , geographically located at $121^{\circ} 15$ ' E- $125^{\circ} 11^{\prime} \mathrm{E}$ and $9^{\circ} 19^{\prime} \mathrm{LS}-10^{\circ} 57^{\prime} \mathrm{S}$, with a borderline - i.e. borders the North Sea borders the Savu sea, Strait of Ombai, bordered to the South by the Indian Ocean, the East borders the County of TTS and Ambeno/Timor-Leste and to the West is bordered by Rote Ndao Sabu Raijua Regency and the Savu sea.

Kupang regency is a Regency tofografinya mountainous and hilly with slope up to 450 degrees. The surface of the soil is bare so critical and vulnerable to erosion. However, in the expanse of the plain is fertile land and an area where normally a resident of Kupang is concentrated there. A tofografi like this give rise to physical isolation,economic isolation and social isolation, much less by a lack of support infrastructure such as roads and bridges in various districts. While certain islands of transportation is often rather expensive because of the low frequencies of the means of transportation to many of the Islands, and it is surely also affect the price of goods and services of a particular

The climate is dry and Kupang regency, according to b. r. Oldemam of type D4 andE4, with climatic conditions like this then the season very short i.e. 3-5 months, whilethe dry season 7-8 months. The short rainy season it only happens in December until March. These circumstances make the agricultural sector into dry land farming and be made wet tropical forests that existed in Kupang is relatively homogenous and dry when the long dry season.

In terms of population, the population of Kupang increase static enough starting from 2005 until 2008 and decline in 2009 , with the last data acquisition total total population amounted to 303,998 inhabitants in 2009 . For the year 2012 recorded residents of Kupang numbered 344,008 inhabitants, with details of men and women 172,395 soul 171,613 soul. Density is 58 persons per $\mathrm{km} 2$. As many as $47 \%$ of this population is the population aged 20 years and under (BPPS Kab. Kupang,2012)

\section{Description of the school where the location of Research}

The location of this distinguished research over the location of local wisdom data "that is in the village of Baumata East of the change of data" and knowledge of the environment and the change of attitude of students in Kupang West SMAN 1. 
According to the data in Kupang there are 54 schools with details of 42 SMA negeri and 10 private-run High School. As well as a religious-based schools 2 under theMinistry of religious affairs namely the Madrasah Aliyah (MA) and Theological High School in Kupang and many are developed according the needs of the education community, because the amount of data on the 2012 High School in Kupang only 37 only (data from Head of Office Ministry of Education Kupang District, SMA/MA/SMK Kab Kupang).

Based on the results of the interview publicly with Kasi produce educators Yermias Eik,S. Pd obtained info that all school curriculum have implemented High School 2013 although his last until the researcher took data reset to Office of education youth and sports (PPO) Kupang Regency dated 12 October 2014 have not been distributed to the school because it has not yet been submitted by printing. Procurement constraints book is one of a large number of curriculum implementation constraints 2013 in addition to the lack of understanding of the teacher, confusion and some syllabus devised a way of assessment of students are diverse, all of which some are poorly understood by the teacher.

There are 2 schools which became the parent school since first implementing curriculum 2013 i.e. SMA 1 Kupang Kupang West and East High School 1, so other schools "grafting" of two schools shall include. Until this time socializing and related training curriculum intensive still implemented the 2013 so that expected next year allconstraints can be minimized and the school was already really ready to implement curriculum 2013.

It is generally ranked in national exam results (UN) NTT province are still far from the expectations that is revolved around 32 ranking for the years 2013 and 31 for the year 2012. For SMA Kupang alone also ranked only 12 province of NTT which means still need improvements by many parties despite ranking only National assessment exam results is one indicator of the success of the education.

Some of the constraints related issues education as expressed above is the lack of teachers who are really professional and school infrastructure. For teachers there is a High Schoolteacher with a total of 993 students 12,960. Of that number there are 128 teachers and teachers contract, with the status of honorary guru and Governmen teacher.

As for the field of study of biology teacher was only 106 people which means less than 2 person persekolah, because based on the latest data on Kasi PTK there are 4 schools that do not have a biology teacher and "borrowing" from other schools. These constraints according to Head Office Ministry Of Kupang District SMA/MA/SMA Eliazer Teuf, S. Pd, is because there are some new school that has yet to get a teacher or still in the process of removalor appointment of teachers.

While the concerns means and parashara schools also remains a serious constraint because of the construction of the school building was arranged to avoid miss appropriation of funds. So for the construction of exactly through the bureaucracy. In addition many new High School still hitch hike in other schools such as SMA 2 East Amfoang still aboard the in SD Negeri Amfoang East. According to the principal X Fansiscus Asii, construction school building Fund has yet to slow down and school difficulties, where as particularly school have been standing since 2010 .

A number of obstacles still coupled with the breadth of the area of the administration of Kupang which stretches from the Western tip of the island of Timor up to the border with the County of TTS following some of the Islands make extra work must PPO Service hard oversees schools in his area. Not to mention the connecting road conditions and some of the constraints of transportation as well as distribution area is great and there is remote because of the difficult topography as a course of Amfoang in broken and bypassed the River, as well as the Sub-District of the island is the pairs apart, separated from the island of Timor.

Of the entire HIGH SCHOOLwho scattered in all corners of Kabupeten Kupang, researchers took 4 school HIGH SCHOOLas the school survey to get the initial data i.e. SMAN 1 Kupang Barat, SMAN 1 Central Kupang, Kupang and SMAN 2 SMAN 1 East of Kupang. The location of the object of research is the SMA Negeri 1 West Kupang, located on the Western tip of the island of Timor with a distance of approximately $25 \mathrm{KM}$ from the city of Kupang. SMA Negeri 1 Central Kupang is around $22 \mathrm{KM}$ from the city of Kupang, SMA Negeri 2 Kupang Tengah (now called Sman Taebenu) which is located approximately $20 \mathrm{KM}$ from the city of Kupang and SMA Negeri 1 Toured East located at Oesao about $30 \mathrm{KM}$ from the city of Kupang.

From school - school, the researchers took data learning biology in school as well as the perceptions of teachers towards learning biology. The latter is taken 2 SMA SMA i.e. 1 HIGH SCHOOLand West Kupang Kupang Timur 1 because it already implements the curriculum of the school as a limited test of 2013 or test a small class and the test class or test extensively on product development are learning Biology class X that can increase the knowledge and attitude of students in maintaining environmental sustainability. But in researcher, X-grade biology teacher SMA N East Kupang experiencing time constraints and health so that it can not be used as the test class, so all product test done just in West Kupang SMA 1 i.e. class X Science test for small class 2 and class X 1 Cross Bio Biological interest. 
Based on the results of the initial survey researchers about the condition of the schools, as well as interviews with the principal and then retrieved the data i.e., the identity of the school, school facilities and infrastructure, the number of groups of learning or learning conditions, the number of classes, the number of teachers ofbiology,supporting environmental learning, learning media availability.

Based on the results of that then it can be said that the condition of the school by default is sufficient, such as a qualified school building, the existence of the school has a wide open green space, the bathrooms are eligible as well as classrooms. The presence of a library with a textbook and a book supporting learning.. But the requirements or equipment needed in the activity of learning experience constraints limited the number of teachers of biology, not innovative learning media, a book that is both common and biology and lack of teacher's Handbook.

Despite getting the socialization Curriculum teacher knowledge about 20132013 curriculum is still not adequate, there are even some teachers who remembered hearing only.

Teacher creativity in choosing approaches, strategies or methods of learning the optimal yet too. They are still building on learning activities and teaching, not to the level of learning, so that only knowledge transfer occurs without a clear concept inculcated in students learning material so that there is less sharpening students to seek more and make them more active. Of the four new schools that, SMAN 1 Kupang West and and East Kupang SMAN 1 already carry out Curriculum 2013.

\section{Description of the village of Baumata East of Spot Data capture of local wisdom}

Researchers dig into local wisdom society as the largest tribe that existed on the island of Timor, and it is a community group that has local wisdom in maintaining environmental sustainability. The community of the island of Timor has a lot of tribes, such as the Molo, Missa, Amafnay, Nai usu, Tkesnai etc. However technically Timor also frequently identified with the tribe, a tribe of Amanuban Boteni, Dawan, Helong, Kemak, Belu.

To Kupang, the tribes are common in the society is the Dawan Timor tribes historically is the term for the Portuguese nation Atoni meaning people inhabit dry areas and exclusively the area of Amarasi, Fatuleu, Amfoang, Amanuban, Amanatun, Miomaffo, Biboki and Insana, Kupang. In the Kingdom, the nation was scattered in the Kingdom Amanatun Atoni, Amanuban, Molo, and Taebenu.

Researchers take the place of local wisdom material retrieval in the village of Baumata East of the former was part of the kingdoms of the Nations that are the Atoni Taebenu. The Kingdom of Taebenu stretching from Baumata, Baun, Mantasin, up to the Oenesu and surrounding areas and during the colonization of the Netherlands was part of the territory of the Kingdom of Kupang (Luitnan, 2012:82-87).

East Baumata village is one of the villages in the Sub-District of Taebenu, Kupang Regency consisting of 5 hamlets. The village is bordered by the villages of Baumata 1 Centre, Hamlet 5 borders the village of Kuaklalo, village Baumata Village bordering2 North. Livelihoods are mostly Farmers. Neighborhoods in the village of East Baumata belongs to dry enough that is not a lot of water around the House every population there has always been a plant that makes the House look green. Plants grown not just interest that serves to beautify the home but also there are crops that can beused as food ingredients such as banana, cassava, jackfruit, cashew nuts, and so on.

The main source of livelihood is agriculture wetlands and dry land in accordance with the existing natural conditions with simple farm equipment still retain mutual pattern in open land, plant, and harvest. Dry land agriculture dominated plant palawijaya such as maize, beans and rice. In addition the community Baumata generally also cultivates mamar. Mamar is a garden that is generally located near the source of the planted with various crops economically like bananas, betel nuts, coconuts, jackfruit, and some types of crops simultaneously.

Traditional agriculture is highly dependent on the weather cycle, because the rainy season is quite short of the cycle. For agriculture such as rice paddies, settled communities generally start after the rainy season begins around January or February. Are for dry land farming begins with clearing of land and burn that started around July or August. While planting normally begins in December.

From the observations and interviews conducted on the community Baumata the East can be seen that in general the community Baumata have a good knowledge against plants and animals that were around their environment and have the wisdom to the environment by keeping it properly and not ruin it. It can be seen that all the plants around the House well-kept lawns and planted in groups based on their function, such as ornamental plants, ornamental plants fellowcombined crops planted together seasoning plant vegetables. Although not specifically take care with fertilizer routine but respondents said they keep the plants in the court yard house with planting and keep not dead or damaged. 
East Baumata communities is the community which has the uniqueness and distinctiveness of his life. It can be seen from the way of life that is still very simple and in harmony with nature. Almost all her life needs are met from nature. Utilization of nature is done using traditional knowledge, so that naturalconditions in the region of East Baumata still well preserved.

The behavior of the community Baumata East to guard and preserve nature is a form of worship in running their obedience in accordance with adhered. The community of East Baumata assume that they have a duty to safeguard and conserve nature.

The environment surrounding the House is used for planting flowers, even used also for growing plants that can be used as food ingredients such as banana, cassava, corn, pumpkins, beans and rice, although local communities have a plantation that is located far away from home. East Baumata people's livelihoods are farmers. The results were being partially used for daily food and partly again sold to meet daily needs as well as to finance the education of their children.

B. Research results

From needs analysis conducted, researchers then created an instrument that can be used to obtain preliminary information in the plan the preparation of the RPP, textbook, students worksheet, Media and reserved THB. Further material will be developed, validated, corrected and tested. The following will be discussed one by one in the order ADDIE model.

\section{Analysis of the material}

Researchers distribute learning material needs analysis kuisoner you want to add and pasted on a device of learning Biology class x. Kuisoner the researcher to miss out on teachers, community leaders, as well as communities that are considered to havea concern for education. There were 50 Respondents that returns and answer the kuisoner and most agree need for additional material that can contribute in the formation of students ' attitude so that care and want to maintain environmental sustainability.

Respondents also want the insertion of the value of local wisdom in learning, especially Biology because it is an effective way to remind and teach again values either in the local wisdom.

Following the local wisdom from Baumata Village East community relate their knowledge about plants, animals, and the way they treat nature with wisdom about natural care environment and rituals associated environmental sustainability. All the data is already with triangulasy with Timor's cultural experts Dr. Gregor Neonbasu and can be seen in table 4.1 below:

Table 4.1. Local wisdom of Baumata Community

\begin{tabular}{|c|c|c|c|c|}
\hline No & Knowledge about Plants & $\begin{array}{l}\text { Knowledge } \\
\text { of Animals }\end{array}$ & $\begin{array}{l}\text { Knowledge of indigenous } \\
\text { rituals associated } \\
\text { environmental care }\end{array}$ & Other forms of natural care \\
\hline 1 & Potentially drug plants & Animals for livestock & Omen syukur & Fine custom \\
\hline 2 & Plants for food & $\begin{array}{l}\text { Animals for } \\
\text { ritual customs }\end{array}$ & Fua pah & $\begin{array}{l}\text { The Concept } \\
\text { "Mansian-Muit-Rice, } \\
\text { Na Bua" }\end{array}$ \\
\hline
\end{tabular}

3 Herbs for rituals customs

Atoni pah meto

Paonasi

From the table it can be seen that in general the public Baumata have a good knowledge against plants and animals that were around their environment and have the wisdom to the environment by keeping it properly and not ruin it.

There are 10 topics in Learning Biology taught in class X curriculum based on 2013, namely: (1) the scope of biology, (2), (3) Archaebactheria and Eubachteria, (4), (5) Protists. Fungi (Fungi), (6). Biodiversity, the world of plants (7), (8). Animal world (9). Ecosystems and (10). Environmental Science. To the topics outlined in the ten-four (4) core competencies (KI) and 23 (twenty three) Basic Competence (KD). Of the $23 \mathrm{KD}$ the KD 10 (ten) that can be inserted with the local wisdom of Timor (Ardan et all, 2015)

There are four (4) Biological material grade X i.e. Material, material World biodiversity of plants sub material classification of plants, ecosystems and Materials Material environmental science which can be inserted with the local wisdom of Timor, in the form of local wisdom about the rescue of the environment, clean water, trapping knowledge 
classification of plants, animals, knowledge of traditional medicines and health care, utilization of materials for the manufacture of traditional tools. In addition local examples will be inserted in the form of animals and plants native to Timor, examples of existing conservation in Nusa Tenggara Timur (NTT), customary fines local wisdom, traditional ceremony about the maintenance of nature such as the ceremony of "the Omen," Thanksgiving Ceremony "Fua Pah", as well as the use of natural dyes used in yarn dyed woven fabric to make a Bunch of Timor (Ardan, et all, 2004)

Environmental rescue local wisdom is reflected from the principle "Atoni Pah Meto" inherent in the original community identity of Timor, in the form of patterns or ways of living humans, where they perceive the surrounding environment such as lawns, fields or gardens as little world (mikrokosmis), which are among the great world/outside (makrokosmis) and must be in harmony side by side

\section{Designing a learning device}

Some of the things that is the basis or consideration of design product development study in this research include: recapitulation of the initial observation and the results of the excavation of the local wisdom of Timor, which is done by the method of survey, basic competencies, core competencies and competency standards outlined in the curriculum of 2013. All products are made to the learning of the class X Biology and biodiversity with the material basis of the classification of living organisms, ecosystems and environmental science. Products that will be produced there are five (5) IE: Draft implementation of learning (RPP), textbook, Student Worksheet, Media of learning and Learning Results Test Problem (THB) which consists of a Test of knowledge and Attitude Test.

After all the design of the products are made in the form of hardcopy, then carried out the validation process by 3 people i.e. education experts, namely Dr. Geradus Uda, M. Pd, expert knowledge of the environment, namely Prof. Dr. IR. Gufran Darma Dirawan, URM.EMD as well as an expert on biology education at the same time the Timorese community leaders Dr. Paul Taek, MS.

So with the validation, assessment and improvement of the product, then one of the goals of this research are already achieved, namely to describe Biological learning device i.e. RPP, learning materials, media and students worksheet, $\mathrm{X}$-grade HIGH SCHOOL on the topic of biological diversity and of the basic classification, ecosystems and environmental issues based on a valid Timor local wisdom.

The resulting product and has been validated by the experts above, tested to a limited cobakan or commonly called the test a small class on class X students. The result of the test classes are small (Small groups) are described in the following row.

\section{Implementation of a learning test}

Implementation of learning as part of the class test is carried out in two stages, namely the stage of test classes small and large class test stage.

a. small class Test

To analyze the content or content, then the following described the process of learning by teachers of biology to applied to the classes X SC. 2 as a test product to a limited extent. Learning consists of 4 times during a 3-hour lesson, as stated in the syllabus and the RPP, with taking Biodiversity chapter and basic classification of living things. Data implementation of learning that researchers got from teacher, observer and learning video observations

After all the related data is grouped in small classes, test researchers are discussingagain some improvements that need to be done for the RPP, learning materials, students worksheet, and discuss it with the biology teacher. In addition researchers also mewancarai biology teacher who became executor of device development learning in class. From the results of the assessment of teachers as well as the process of implementation of the learning in the classroom, then it can be concluded that in general the RPP, textbook, teacher's book and media is categorized, the book students as well as RPP is acceptable and can be implemented by biology teacher. To analyze the content or content, then the following described the learning process by biology teacher Alfredus Rudy Soetarno, S. Pd. for class X Biology applied to the as a test product to a limited extent. Learning is planned to consist of 3 sessionsfor 3 hours of instruction as stated in the syllabus and the RPP, with taking Biodiversity chapter and basic classification of living things. Data implementation of learning that researchers got from teacher,observer and learning video observations.

A large class of the test can be seen that the liveliness of excellent students in the process of pembelajarn, the teacher gives the average rating for each product above 3.5 , assessment of students to that on average students respond very well to the product being made, where the value of the given range from 3 to 4 which includes the categories very well. 
Evaluation and analysis of all of the above, then the data device can be taken so that practicality can be said that a learning device developed for practical use by the classroom teacher HIGH SCHOOLas a supplement book X in the Biology of learningbased on the curriculum of 2013 at this time.

4. Experiments to test the effectiveness of a learning device.

To measure how effective a learning device is developed, then there are 2 things that need to be seen are (1) perform tests of knowledge of students, and (2) did the test the attitudes of students. The second test it while also being part of the stages of research, i.e. phase 3 as stage experiments. This step needs to be looked at, as to find out whether there is an increasing environmental knowledge of students and student attitude change for the better in maintaining environmental sustainability due to the granting of study with biological devices that are already developed.

Experimental design usedwas pre test post test one Biology class with group Kupang West as class experiments, with a total of 32 people, but students who test just 27 people. One of the things that became the goal of this research is looking at changes to environmental knowledge and attitude of students students who made the research sample. To see these changes then conducted tests.

Matter knowledge tests are made in the form of multiple choice IE the initial tests by as much as 30 numbers and final tests as well as many as 30 numbers. There is nodifference in content for initial tests and tests the question of late, but just differentnumbers just because researchers do randomization. In addition to the knowledge test was performed also tests the attitude in which researchers share the reserved attitude of the tests at the time before granting a product study conducted and after product use in learning. Because it is measured is the attitude, where attitudes as an invalid constructs psychology must satisfy two criteria that is observable and measurable. Attitude is a positive or negative trend of identity to a specific psychological object. To measure the attitude should be constructed scale attitude, starting with determining and defining the attitude of the object to be measured or with other klata "attitude towards what?".

For that researchers using Likert scales that is already commonly used to measure attitudes. There are 25 statement to choose students whether they strongly agree (SS), disagree (S), undecided (R), disagree (TS) and strongly disagree (STS). So there is a choice of 5 assuming the attitude of SS and S are categorized well, R as a neutral stance and TS and STS are categorized as not a good attitude. Subsequent to notice any difference in initial tests and tests end used korelasional t-test dependent. So from both kinds of tests, tests of environmental knowledge andattitudes acquired test results as indicated in table 4.2 .

Table 4.2. The results of the measurements of environmental knowledge and attitude of students

\begin{tabular}{lllll}
\hline NO & The variables measured & the value $\mathrm{t}$ calculated & the value $\mathrm{t}$ table & decision thit $>\mathrm{t}$ tabel \\
\hline 1 & The knowledge the student & 7.3 & 2.77 & There is a difference \\
2 & The value of the attitude & 6.5 & 2.77 & There is a difference \\
\hline
\end{tabular}

TEST ANALYSIS of CORRELATION TABLE $t$ DEPENDENT TEST TWO PARTIES with $\alpha=0.05$

From the table it can be seen that there is a difference to environmental knowledge and students value the attitude of students, so that it could be said that there is a significant improvement to students ' environmental knowledge and attitude of students of class X Biology 1 in maintaining environmental sustainability before and after administering the device learning Biology-based local wisdom of Timor.

Thus it can be concluded that the device learning developed effective use by students of class $\mathrm{X}$ at the moment because it can increase the knowledge and attitude of the students. So one of the goals of the research are already being met to analyse the increasing knowledge and changing attitudes of students after the given device learning of biology.

\section{Discussion}

The last prototype of the product are Learning implementation plan (RPP), textbook,Student Activity Sheets, Media learning and Test the results of the Study (THB) as Biology learning device development products with the local wisdom of Timor to improve environmental knowledge and attitude of students in maintaining environmental sustainability at grade X SENIOR HIGH SCHOOLin Kupang.

All test results of student's attitude in fact does not immediately change the attitudes of students, although based on the radar of researchers, an atmosphere of cleanliness class and in front of the class page Bio 1 did better than when the initial research. 
Based on the random and unstructured interview on grade Bio 1 about the attitude of maintaining environmental sustainability students expressed that attitude is very important and they realize that turns carve out a live tree is the Act of damaging the environment, as well as the habit of breaking a limb or tree for no reason. So didthey realize how rich Indonesia and also the NTT and the island of Timor with different kinds of plants and animals that are either rare or endemic and feel proud of that knowledge.

All of the information they get from the learning process by using a device of learning Biology-based local wisdom Timor they already get a trial class. They feel proud of the types of plants and animals that exist in East Timor and it is evocative of their consciousness to better safeguard environmental sustainability so that they will maintain the types of plants and animals.

Of the above, the purpose of the research is to create a fun learning devices by adopting local wisdom values of East Timor can be said to succeed. The success of this is seen from the spirit, the response as well as a very high student activity in any learning with the use of the device. So it can be inferred that the learning that has been developed effectively in order to improve the response of the students, the activity of the students as well as the achievements of the student learning.

From the third point above, namely (1) the last validation, (2) and (3) the practicability of its effectiveness, then the 2nd prototype (after appropriate revision advice guru model) which is a prototype of a device of learning developed in this research, it can be used in class X (prototype 2 attached at Appendix 10). Learning devices include a draft implementation of learning (RPP, textbook, Student Worksheet, and the Media learning and Learning Results Test Problem (THB) which consists of a test of knowledge and attitude test.

Compared to the Biology learning devices have been used by teachers for this are usually composed of RPP made by a teacher, a text book published by National publishers like Esis, Intan Pariwara, and others, in the worksheet focus, as well as the question of THB made by teachers that contains biological material are common.

The examples that were given many don't understand the students, the lack of material environmental knowledge, the absence of environmental wisdom material that can be used as role models by students so that raises awareness in maintaining environmental sustainability.

For the development of environmental education, the lack of material inserts on the subject matter that should be used as a means of evocative awareness of students about the importance of maintaining environmental sustainability to safeguard the Earth and so that still provide benefits for humans. Learning developed devices have more value on material environmental knowledge by giving examples of real, one can see students so it will make students realize the importance of good environmental knowledge.

This result makes mobile learning has developed value added as a learning tool students and additional information make teachers and students. In terms of the biological sciences, awarding examples of plants, animals and ecosystems typical of NTT and the island of Timor is new to textbook biology, because so far, all the information was just being an interested researcher consumption steeped in the science field of study, so that students and teachers don't get that information. Whereas such information is a knowledge environment that can be used as a means of evocative awareness of students in maintaining environmental sustainability.

\section{Research findings}

From the process of needs analysis, product design, validation, implementation of the test in class, revisions and improvements to the product so that it produces a prototype 2 consisting of RPP, textbook, it students worksheet, Media and reserved product learning device then THB Biology Classes X-based local wisdom of Timor is the principal findings in the field of PKLH because these products can increase students ' environmental knowledge and change attitudes for the better students in maintaining environmental sustainability.

That to increase environmental knowledge and change the attitude of the students in maintaining environmental sustainability one of the spacecraft that can be used is a Biology-based learning local wisdom of Timor. The entry of local wisdom can make students more easily in the absorbing material learning. The closer the students with their environment, the easier it is to understand the problems and are looking for answers related problems. So that the device is capable of being developed learning innovation in learning Biology class X and viable was developed for the class XI and XII. 


\section{Conclusions and Suggestions}

\section{A. Conclusions}

Based on the formulation of the problem in this research as well as a description ofthe data analysis in chapter IV and discussion, so some of the conclusions that can be derived as follows:

- $\quad$ Product learning device that was developed in the form of (a) Learning implementation plan (RPP), (2) X-grade Biology textbook with the local wisdom of Timor for teachers and students, (c) Student Activity Sheets (d) media director for micro Learning Material for biological diversity, power point to the material of the biodiversity, ecology and environmental science, media Puzzle map and Biodiversity of ecosystems once validated and tested is valid and practical.

- Wants Results to increase environmental knowledge in students of class X 2 Bio SMAN 1 Kupang West there is a difference in student learning achievement significantly before and after the use of a device of learning developed.

- The results of the attitude for improvement of students wants in maintaining environmentalsustainability at grade $\mathrm{X}$ Bio 2 SMAN 1 West Kupang showed that that there is a change in the attitude of the students become better in maintaining environmental sustainability both before and after the use of a device of learning developed.

\section{Acknowlwdgement}

Thanks to The Ministry Of Research and Higher Education through competitive grants that funf this research and to Nusa Cendana University for permit the implementation of this study.

\section{References}

Anonymous. (2004). General Guidelines For The Development OfLearning Materials From High School. Jakarta: Department Of Education Republic of Indonesia.

Ardan, M. Ardi, Y. Hala, A. Supu, G. Dirawan. (2015). Lokal Wisdom Of Baumata Society in Kupang Considering The Nature Perservation. International Journal Development Research Vol Ardan,

Ardan, M. Ardi, Y. Hala, A. Supu, G. Dirawan. (2015). Need Assesment to Development of Biology TextBook for High SchoolClass X-Based The Lokal Wisdom of Timor. International Education Studies. 8(4), April 2015.

Borg, R. W., Gall, Meredith. (1989). Educational Research: an Introduction. Fifth Edition. Longman.

Dick, w., Carey, 1., \& Carey, J. (2001). The Systematic Design of Instruction (5th ed.). Allyn \& Bacon.

Gay, L.R. (1981). Educational Research. 2ndEdition. London: Charles Merryl Publisihing Company.

KBBI. (2008). Online http://badanbahasa.kemdiknas.go.id/kbbi/

Gazette Of The State. (1945). the Preamble of the Constitution of the State of INDONESIA in 1945.

Gazette Of The State. (1987). The DECREE of the Minister of education and culture of INDONESIA No. 0412u/1987 on 11 July 1987.

Luitnan, Isaac, A.. Koepang Tempo Doeloe. Jakarta: A Community Of Bamboo.

Manehat, p. (2012). View Of The Timorese Against The Natural Surroundings. In a Cultural Agenda In Society. Editor Gregor Neonbasu. Jakarta: Kompas Gramedia. 